\title{
RESULTS OF A 3-YEAR BEACH EROSION CONTROL PROJECT IN HILLSBORO BEACH, FLORIDA, UTILIZING PRESSURE EQUALIZING MODULES (PEM)
}

\author{
Kenneth Christensen ${ }^{1}$ and Frank Gable ${ }^{2}$
}

\begin{abstract}
The patented PEM system is a passive beach dewatering technology consisting of hollow permeable tubes installed vertically into the beach in a grid pattern. The system requires no pumps or energy to operate. At Hillsboro Beach, Florida the system was installed for a 3-year period at a highly eroding part of the beach where the shoreline historically had lost $25.2 \mathrm{ft}$. $(-7.7 \mathrm{~m})$ in 3 years. By the end of the 3 -year period the shoreline in the 1-mile PEM project area had advanced $26.9 \mathrm{ft}$. $(8.2 \mathrm{~m})$, erosion had stopped, and the PEM area had accreted from R-monument line to MHW, to -5ft NAVD, and to DOC without the control areas to the North and South being negatively affected.
\end{abstract}

Keywords: PEM; beach dewatering; beach drainage; passive drainage; beach erosion control; EcoShore; Hillsboro Beach; Pressure Equalizing Modules;

\section{INTRODUCTION}

Pressure Equalizing Modules (PEM) is a patented passive dewatering technology that improves beach drainage. Where applicable PEM will reduce or eliminate the need for traditional beach nourishment. PEM has been used internationally for over a decade by several large contractors; however, Hillsboro Beach was the first US project, and the target was to outperform the control areas by $>25 \%$. The PEMs were installed for 3 years, from the middle of February 2008 to the end of January 2011.

\section{TECHNOLOGY}

PEM's are hollow permeable tubes inserted vertically into a beach in a grid from the dune to the mean low waterline. The tubes are placed one to three feet under the beach surface making the installation completely invisible. The exact grid design depends on the local conditions. The tubes are not connected, and no energy is used to operate the system. The tubes penetrate and connect the different strata of the beach allowing the water to find the easiest way out by gravity during the falling (outgoing) tide, typically via a coarser layer, resulting in improved drainage as illustrated in Fig. 1.
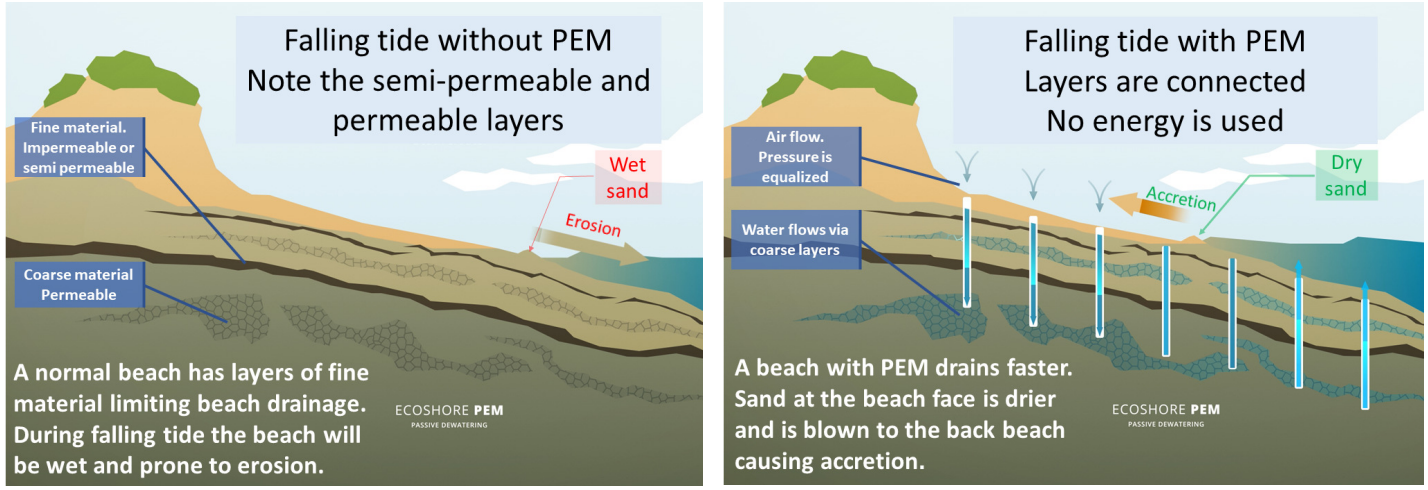

Fig. 1 - Working mechanism of the PEM system

A vent at the top of the tube connects to the atmosphere allowing pressure to be equalized, hence the name PEM - pressure equalizing modules. As a result, the time period where the beach is saturated and prone to erosion is reduced. With improved drainage (Turner and Leatherman 1997), more sand is deposited in the swash zone and via aeolian transport moved to the back beach and dunes, resulting in reduced erosion and, more often, accretion.

During storms a PEM area is proven to lose less sand and build up faster after a storm (Ekkelenkamp 2011). PEMs cause no down-drift erosion, no escarpments, and have a proven turtle friendly design. The carbon footprint is minimal as they require light-weight equipment to install and no pumping to operate.

\footnotetext{
${ }^{1}$ EcoShore Int'I, Inc., 2255 Glades Road, Suite 324A, Boca Raton, FL 33431, USA

2 Department of Marine and Ecological Sciences, Florida Gulf Coast University, Fort Meyers, FL 33965-6565, USA 


\section{LOCATION}

Hillsboro Beach is in Broward County 35 miles $(55 \mathrm{~km})$ north of Miami, Florida on the Atlantic Coast on a barrier island. The town covers 3.2 miles (5.2 $\mathrm{km}$ ) of beach and stretches from Deerfield Beach (West Palm Beach County) in the north to Hillsboro Inlet in the south, see Fig. 2.

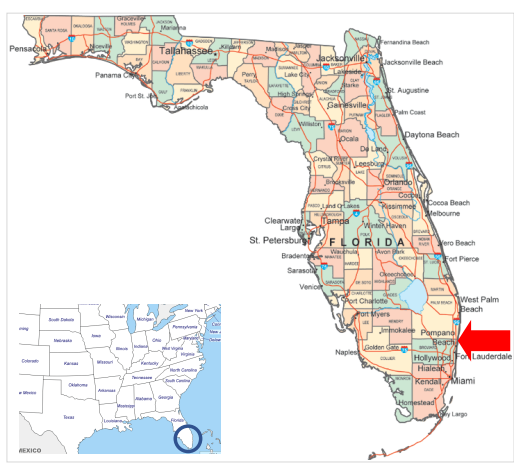

Fig. 2 - Location of Hillsboro Beach

Hillsboro Beach is defined as Critically Eroding by Florida DEP and the northern 1mile (R7-R12) is the most eroding part. This was the location where the PEM system was installed in 2008. Average sand loss from 2001-7 in the PEM project area (R7-12) was -3.9 cubic yards per shore foot (equal to $9.8 \mathrm{~m}^{3} / \mathrm{m}$ ) from R-monument line to depth of closure DOC, whereas the $1 / 2$ mile controls South and North gained 1.2 and $1.9 \mathrm{cy} / \mathrm{ft}\left(3\right.$ and $\left.4.8 \mathrm{~m}^{3} / \mathrm{m}\right)($ Olsen and Assoc. Inc. 2008).

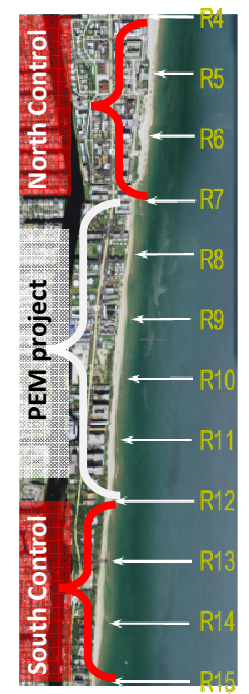

Fig. 3 - Location of project

Groins at Deerfield Beach are likely to cause movement of sand offshore contributing to erosion at R7-8. Hillsboro Beach was found to have a high groundwater table and it is possible that extensive irrigation in the well maintained residential area was a contributing factor. Other elements affecting erosion could be fine layers of silt or clay slowing down beach drainage, a problem PEM is designed to solve.

\section{COASTAL PROCESSES}

The northern part of Hillsboro Beach has been eroding for decades and the latest major nourishment prior to the PEM project took place in March 1998 placing 550,000 cy between R6 and R12 (CEC 2007).

In 2005, Coastal System International Inc. performed an analysis of meteorological and hydrological factors that impact local sediment transport and morphology change. The Hillsboro Beach shoreline is influenced by semi-diurnal tide with an average range of $2.52 \mathrm{ft}$. $(0.77 \mathrm{~m})$ and spring tide range of $2.82 \mathrm{ft}$. $(0.86 \mathrm{~m})$ in the vicinity of Hillsboro Inlet. The tidal period is approximately 12.4 hours.

The wind rose in Fig. 4 shows that winds are predominantly from the east. No hurricanes affected the project.

A statistical analysis of waves indicates that the dominant wave directions are from the northeast and east, with $79 \%$ of occurrences, which results in a net sediment transport toward the south.

During summer, the dominant wave directions mostly are from east and southeast resulting in a northerly sediment transport.

During winter, larger north and northeasterly waves dominate resulting in a north to south sediment

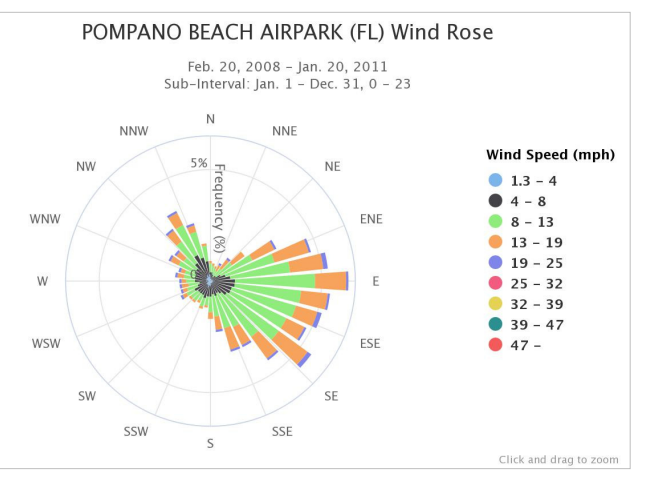

Fig. 4 - Windrose during 3-year project at Pompano Beach a few miles south transport.

During the second 12 month period of operation no major storms or nourishments took place. 


\section{PROJECT}

A PEM pilot study will reveal the hydraulic status of a beach under different conditions and can show if a specific beach will be positively influenced by an installation of PEM. Such a groundwater study was conducted prior to the project. In spite of issues with lost and damaged instruments, it was possible to extract data that showed increased drainage when PEMs were inserted.

The installation of 90 PEMs in 33 rows from the dune foot down to the mean low waterline was completed in less than 2 weeks in Feb 2008 using truck sized equipment, with no beach downtime. Due to a very thin layer of sand at the time of installation, $63 \%$ of the PEMs had to be reduced in size.

Two small truck hauls of sand were placed early in the project at R7 (8,900 cy in June 2008) and in the North control area (7,350 cy in January 2009) and these volumes have been adjusted in the volumetric figures given in this report.

In January 2011, the PEMs were removed by the same Florida certified surveying company that was responsible for the PEM installation as well as all monitoring during the 3-year project in accordance with Florida DEP requirements.

\section{RESULTS AND DISCUSSION}

\section{Meeting success criteria}

After 18 months the PEM project area had met the success criteria as documented by Coastal Engineering Consultants, the town's consulting engineer, resulting in payment of the contractor and the mayor signing a document confirming the results (Appendix A).

Monitoring continued using the same Florida certified surveyor and the same monitoring standards until the end of the 3-year period, when the PEMs had to be removed prior to beach nourishment taking place in spring 2011.

The final survey of volumetric change (MHW, $-5 \mathrm{ft}$, and DOC) and shoreline change was conducted one month after removal of PEM, at which time the sand had started to wash away. Still the data show that sand volume had grown, and the shoreline had advanced as can be seen in Fig. 5, 6, 7, and 8.

\section{Volume change to Mean High Waterline (MHW)}

From the R-monument line to MHW the 1-mile project area used to lose 16,300 cubic yards per year (Olsen and Assoc. Inc. 2008) equal to $-49,000$ cy during the project period. Over the 3 -year period the 1-mile PEM project area gained 3,748 cy of which 2,118 cy could be attributed to nourishment and must be deducted. The net gain was 1,630 cy $\left(1250 \mathrm{~m}^{3}\right)$. The MHW volume change during the 3-year period in cubic yards per shore foot can be seen in Fig. 5 below.

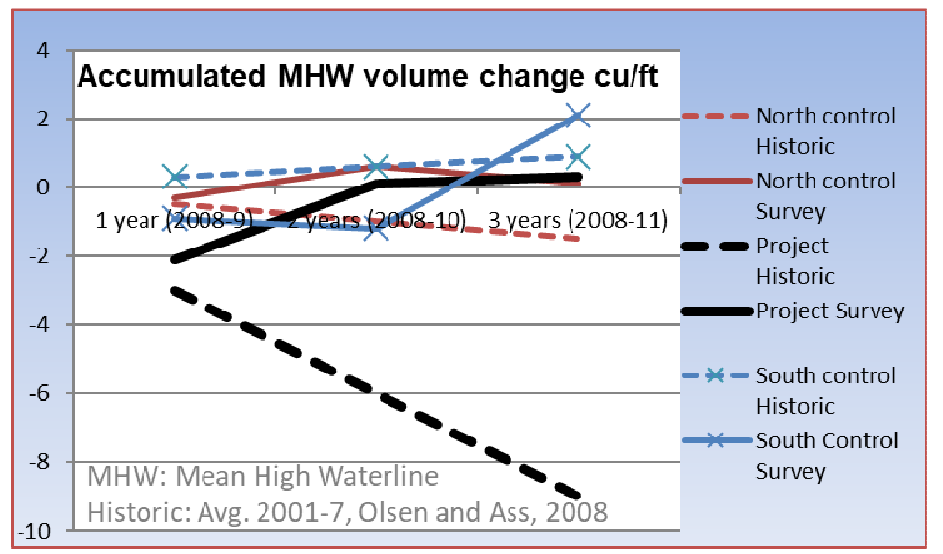

Fig. 5 - Accumulated MHW volume change over 3 years in cubic yards per foot of shoreline. To convert to $\mathrm{m}^{3} / \mathrm{m}$ : multiply cy/ft with 2.5 


\section{Volume change to -5ft NAVD}

Sand volume change to the depth of 5ft NAVD is a very useful standard as it is not as affected by sudden changes in weather as MHW or MLW. However, the survey from Olsen and Assoc. from 2008 does not include survey at -5ft NAVD which is why the figure below has no historic reference.

Over the 3-year period the 1-mile PEM project area gained $10.8 \mathrm{cy}$ per shore $\mathrm{ft}$ or 64,700 cy of which 6,300 cy could be attributed to nourishment and must be deducted. The net gain was 58,400 cy $\left(44700 \mathrm{~m}^{3}\right)$. Volume change from R-monument line to -5ft NAVD during the 3 -year period in cubic yards per shore foot can be seen in Fig. 6 below.

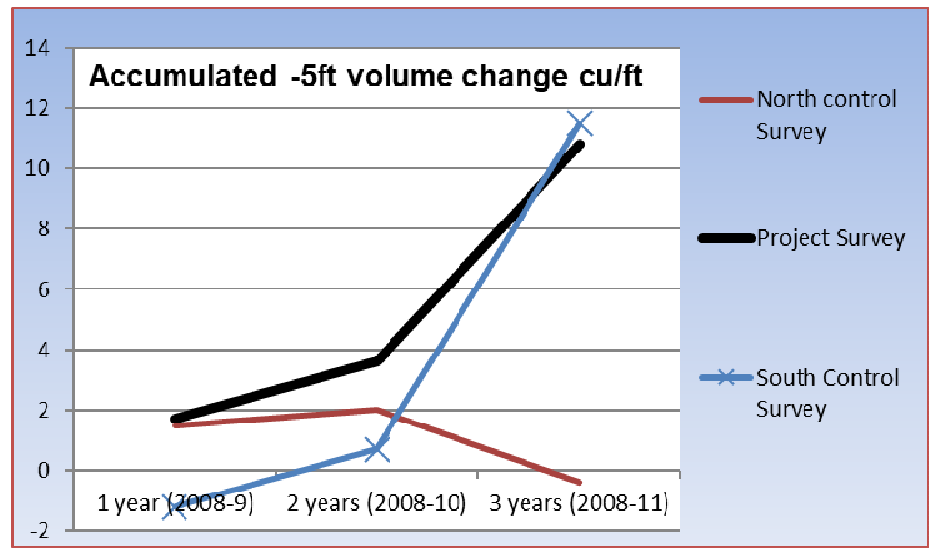

Fig. 6 - Accumulated -5ft NAVD volume change over 3 years in cubic yards per foot of shoreline. To convert to $\mathrm{m}^{3} / \mathrm{m}$ : multiply cy/ft with 2.5

\section{Volume change to Depth Of Closure (DOC)}

From R-monument line to Depth of Closure (-16.57 ft) the 1-mile project area used to lose 21,000 cubic yards per year (Olsen and Assoc. Inc. 2008) equal to -63,000 cy during the project period. Over the 3-year period the 1-mile PEM project area gained 47,000 cy of which 8,500 cy could be attributed to nourishment and must be deducted. The net gain was $38,500 \mathrm{cy}\left(29400 \mathrm{~m}^{3}\right)$. The DOC volume change in cubic yards per shore foot during the 3-year period can be seen in Fig. 7 below.

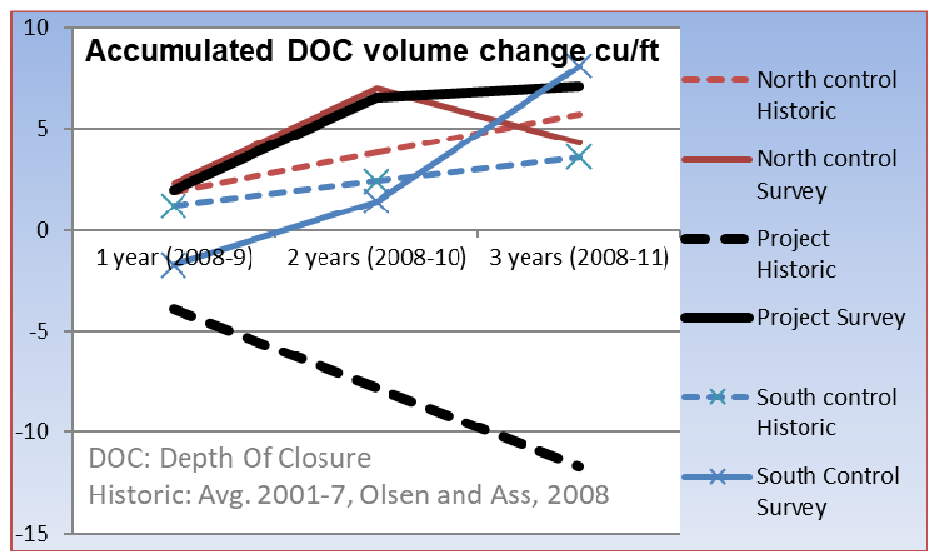

Fig. 7 - Accumulated DOC volume change over 3 years in cubic yards per foot of shoreline. To convert to $\mathrm{m}^{3} / \mathrm{m}$ : multiply cy/ft with 2.5 


\section{Shoreline change}

The shoreline at the 1-mile project area used to retreat $8.4 \mathrm{ft}$ per year (Olsen and Assoc. Inc. 2008) equal to $-25.2 \mathrm{ft}(-7.7 \mathrm{~m})$ during the project period. Over the 3-year period the 1-mile PEM project area gained $26.9 \mathrm{ft}(8.2 \mathrm{~m})$. The nourished sand has NOT been deducted; however, it would only have a marginal effect on the result. The shoreline change during the 3 -year period can be seen in Fig. 8 below.

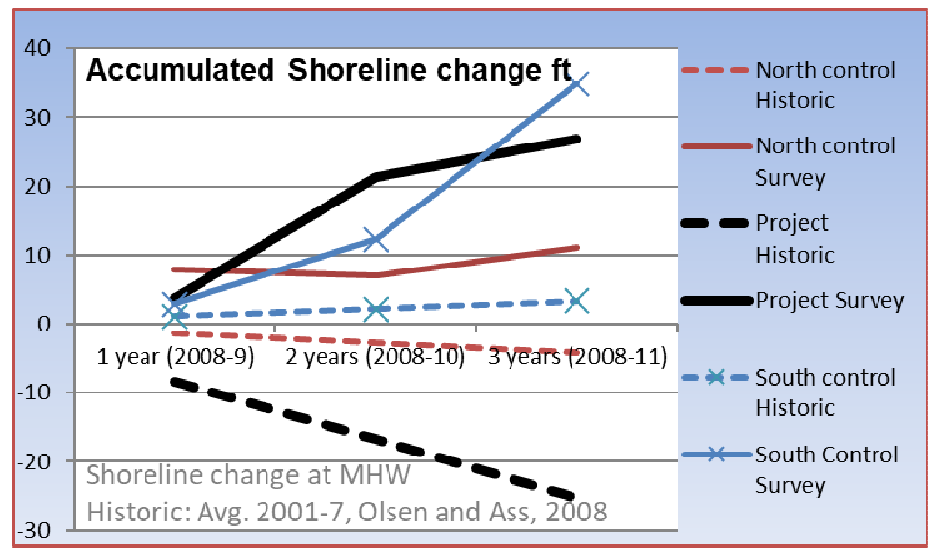

Fig. 8 - Accumulated shoreline change over 3 years in feet. To convert to meter: multiply ft with 0.3048

\section{Effect on downdrift beach}

From Fig. 5, 7, and 8, it can be seen that the PEM project area gained sand instead of historically lose sand over the 3-year project period. The North and South control areas are within the norm. The predominant littoral drift is from North to South and if PEM had caused any negative downdrift effect the South control would be affected. However, the South control performed better than Historic in MHW, DOC, and Shoreline documenting that PEM caused no negative downdrift effect. The result is in line with other PEM projects where the beach downdrift of a PEM area typically accretes.

\section{Results during $2^{\text {nd }}$ full year - a homogeneous period}

During the second full year the weather was stable, and no nourishments took place, making it an ideal observation period. Table 1 below shows the Historic data from 2001-7 (Olsen and Assoc. Inc. 2008) and the $2^{\text {nd }}$ full year $3 / 2009-2 / 2010$.

The North and South control areas fall within the norm. Only the PEM project area is performing radically different from Historic.

The PEM project area historically had lost $3 \mathrm{cy} / \mathrm{ft}$ above MHW $\left(-7.5 \mathrm{~m}^{3} / \mathrm{m}\right)$ but gained $2.1 \mathrm{cy} / \mathrm{ft}$ $\left(5.5 \mathrm{~m}^{3} / \mathrm{m}\right)$. Above DOC the PEM area historically had lost $3.9 \mathrm{cy} / \mathrm{ft}\left(9.8 \mathrm{~m}^{3} / \mathrm{m}\right)$ but gained $4.5 \mathrm{cy} / \mathrm{ft}$ $\left(11.3 \mathrm{~m}^{3} / \mathrm{m}\right)$. Likewise, the PEM project area historically had lost $7.1 \mathrm{ft}(2.16 \mathrm{~m})$ of shore width per year but gained $16.1 \mathrm{ft}(4.9 \mathrm{~m})$ during the $2^{\text {nd }}$ full year where no storms or nourishments disturbed the picture.

\begin{tabular}{|l|c|c|c|c|c|c|}
\hline \multicolumn{6}{|c|}{ Table 1. Historic performance (2001-7) compared to $2^{\text {nd }}$ year - a homogeneous period } \\
\hline & Change above MHW & Change above DOC & \multicolumn{2}{c|}{ Shoreline change } \\
\hline & Historic & $2^{\text {nd }}$ year & Historic & $2^{\text {nd }}$ year & Historic & $2^{\text {nd }}$ year \\
\hline North Control & $-0.5 \mathrm{cy} / \mathrm{ft}$ & $0.9 \mathrm{cy} / \mathrm{ft}$ & $1.9 \mathrm{cy} / \mathrm{ft}$ & $4.7 \mathrm{cy} / \mathrm{ft}$ & $-1.2 \mathrm{ft} / \mathrm{yr}$ & $-2.3 \mathrm{ft}$ \\
\hline PEM project & $-3.0 \mathrm{cy} / \mathrm{ft}$ & $2.1 \mathrm{cy} / \mathrm{ft}$ & $-3.9 \mathrm{cy} / \mathrm{ft}$ & $4.5 \mathrm{cy} / \mathrm{ft}$ & $-7.1 \mathrm{ft} / \mathrm{yr}$ & $16.1 \mathrm{ft}$ \\
\hline South Control & $0.3 \mathrm{cy} / \mathrm{ft}$ & $-0.3 \mathrm{cy} / \mathrm{ft}$ & $1.2 \mathrm{cy} / \mathrm{ft}$ & $3.1 \mathrm{cy} / \mathrm{ft}$ & $0.6 \mathrm{ft} / \mathrm{yr}$ & $7.7 \mathrm{ft}$ \\
\hline
\end{tabular}




\section{Change in beach elevation at PEM location}

Elevation of the beach at the location of each PEM was recorded at the time of PEM installation and at the time of PEM removal. The installation, the removal, and the surveys were done by the same Florida certified surveyor. Average changes in beach elevation over the 3-year period can be seen in Table 2. On average the beach had grown approximately 1 foot $(30 \mathrm{~cm})$ when surveyed at PEM location compared to PEM installation 3 years prior (Christensen, Nettles, and Gable 2015).

\begin{tabular}{|c|c|c|c|}
\hline & Elevation at Installation & Elevation at Removal & Change over 3 years \\
\hline Row $A$ - at MLW & $-2.26 \mathrm{ft} /-69 \mathrm{~cm}$ & $-0.08 \mathrm{ft} /-2 \mathrm{~cm}$ & $2.18 \mathrm{ft} / 67 \mathrm{~cm}$ \\
\hline Row B & $0.21 \mathrm{ft} / 6 \mathrm{~cm}$ & $1.83 \mathrm{ft} / 56 \mathrm{~cm}$ & $1.62 \mathrm{ft} / 50 \mathrm{~cm}$ \\
\hline Row C & $4.46 \mathrm{ft} / 136 \mathrm{~cm}$ & $4.25 \mathrm{ft} / 130 \mathrm{~cm}$ & $-0.21 \mathrm{ft} /-6 \mathrm{~cm}$ \\
\hline Row D - at dune & $4.80 \mathrm{ft} / 146 \mathrm{~cm}$ & $5.45 \mathrm{ft} / 166 \mathrm{~cm}$ & $0.65 \mathrm{ft} / 20 \mathrm{~cm}$ \\
\hline
\end{tabular}

\section{Effect in combination with beach nourishment}

The latest major nourishment in Hillsboro Beach took place in 1998. A report ${ }^{3}$ shows a volume increase from pre- to post-construction between R7 and R8 of 86,000 cubic yards (= starting point and $100 \%)$. As it is common with traditional beach nourishment, the sand gradually eroded. In 12 months the volume between R7 and R8 was reduced to 66,000 cy (=77\% remains). After 50 months only 28,000 cy of the nourishment was left (=33\% remains). See blue "1998 line" with squares in Fig. 9.

The same area (R7-R8) was nourished in June 2008 during the Port de Mer truck haul.

However, this time PEMs had been installed before new sand was added. PEMs work best when enough sand is available, and work well with nourished sand. After the truck haul the volume increase between R7 and R8 was 7,200 cy (= starting point and $100 \%$ ). Nine months after the truck haul the volume between R7 and R8 had doubled, and after 15 months the amount of sand had increased to $260 \%$ of the original volume between R7 and

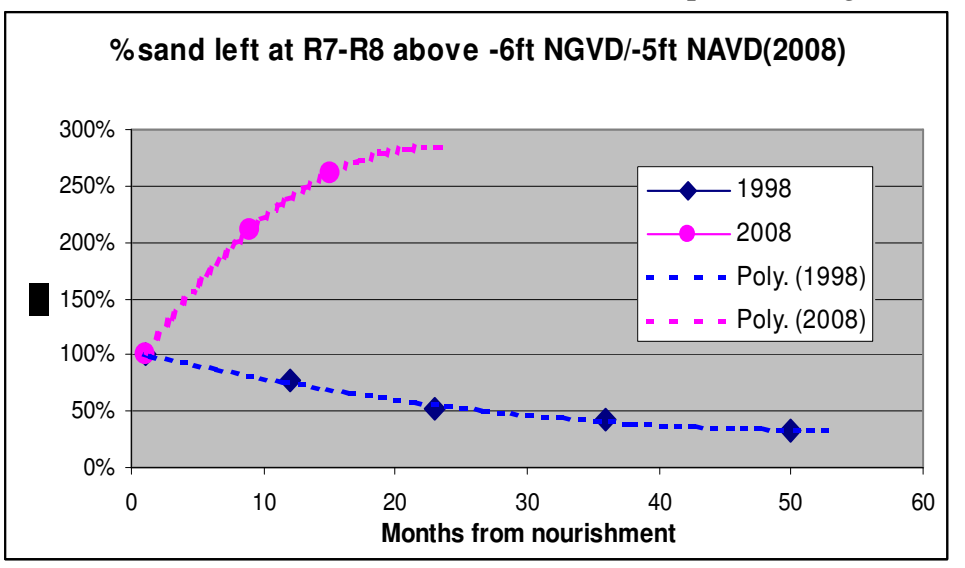

Fig. 9

The graph shows how much sand was left after nourishment. The blue graph represents the 1998 nourishment where sand gradually disappeared. The purple graph (round dots) shows the 2008 truck haul where PEMs were installed before nourishment. The volume of sand was not eroding but increased over time.

\section{R8. See Fig 9.}

This indicates that the PEM system is useful in combination with beach nourishment to prevent the newly nourished sand from gradually eroding, thus prolonging the life of beach nourishments and protecting the investment in new sand. To further ensure longevity of the new sand PEMs may be installed prior to the nourishment, and a second set of PEMs after nourishment. If PEMs are combined with nourishment the volume of added sand can be reduced and the formation of escarpments eliminated which will enhance beach safety and make a recreational beach more attractive to the public.

${ }^{3}$ Hillsboro Beach Deerfield Beach Nourishment Project $4^{\text {th }}$ Year Post-Construction Monitoring Report Oct 2002, Table 3.5 


\section{Environmental results}

A shorebird survey was conducted by a certified shorebird surveyor during installation and no impacts were reported.

A turtle study was performed (Burney 2009) investigating temperature, humidity, nesting activity, nesting success, and hatchling emergence for Loggerhead and Green Turtles. The study showed no evidence of negative affects but noted that the location with the highest number of Green Turtle nests in Broward County was in the PEM project area.

A process like PEM will have different environmental benefits depending on which technology it replaces. The amount of sand accreted to DOC (38,500 cy) plus the amount of sand that would historically have been lost (63,000 cy) (Olsen and Assoc. Inc. 2008) is a way to estimate the volume of sand not having to be replaced via other methods. An amount of 100,000 cy sand will typically be trucked and requires 6-8,000 full dump truck loads, or 12-16,000 return trips at 6-8 mpg. The PEM project has avoided considerable $\mathrm{CO}_{2}$ emissions, wear on roads, noise, etc. but the magnitude has not been quantified.

No incidents relating to endangered species, other animals or people were recorded during the project period.

\section{Visual result}

At the end of the 3-year period, the erosion in the PEM project area had stopped and the beach accreted. This was evident to beach visitors as can be seen in figure 10 and 11 , both shot at low tide.

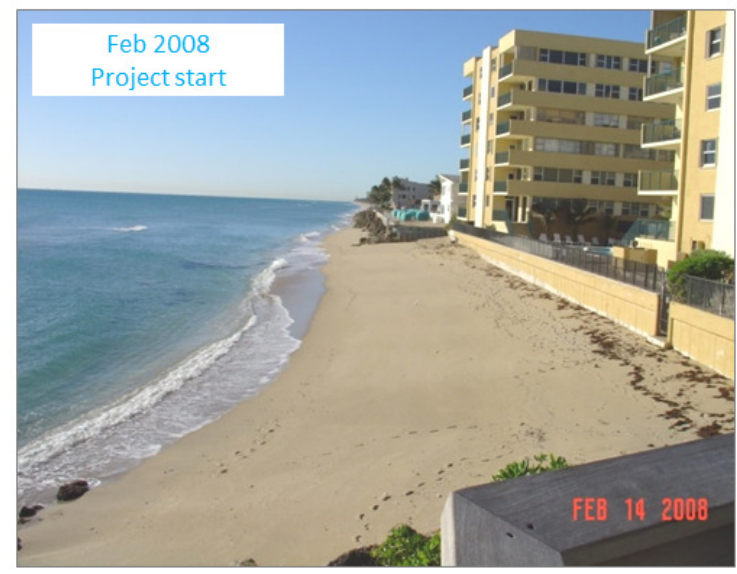

Fig. 10 - Project start at R6.5 looking south

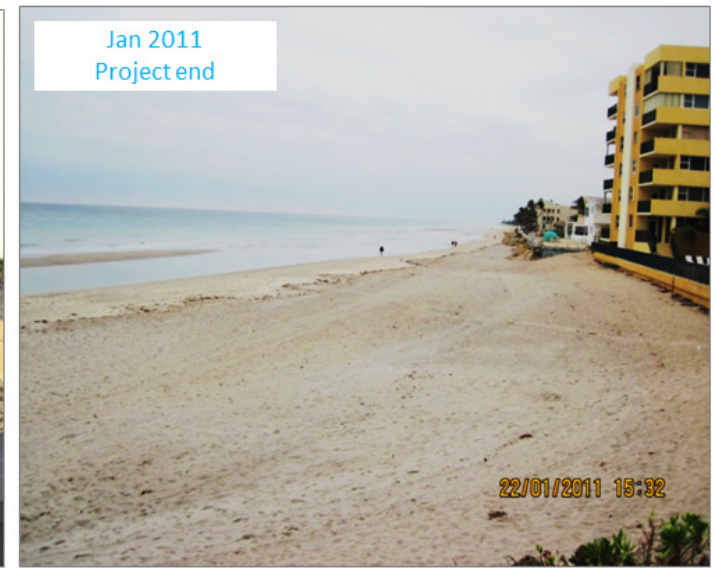

Fig. 11 - Project end at R6.5 looking south

\section{Discussion}

The PEM project area required 18 months to show effect which is more than the usual 9-12 month period. The only reason we can find for the delay is that the layer of sand was sparse when the installation took place resulting in some rows consisting of only one or two PEMs, and more than half the PEMs were reduced in size to accommodate for the thin layer of sand. As the layer of sand grew, the effect increased.

\section{CONCLUSION}

The PEM passive dewatering system was installed at the critically eroding Hillsboro Beach, Florida, USA with the aim of reducing erosion without impacting neighboring beaches or endangered species. The PEM system took a little longer than expected to show a clear positive effect; however, after 2 years the erosion had reversed to accretion and at the end of the 3-year period the beach had gained sand from R-monument line in the dune to Mean High Waterline, to -5ft NAVD, and to Depth of Closure. Shoreline in the PEM project area that historically retreated $25.2 \mathrm{ft}(-7.7 \mathrm{~m})$ in 3 years had advanced $26.9 \mathrm{ft}(8.2 \mathrm{~m})$. The North and South control beaches were not negatively affected, and the downdrift South beach performed better than historically. The project had no negative impacts on shorebirds, turtles or any other species and the highest concentration of Green Turtle nests in Broward County was found in the PEM project area. 


\section{APPENDIX A}

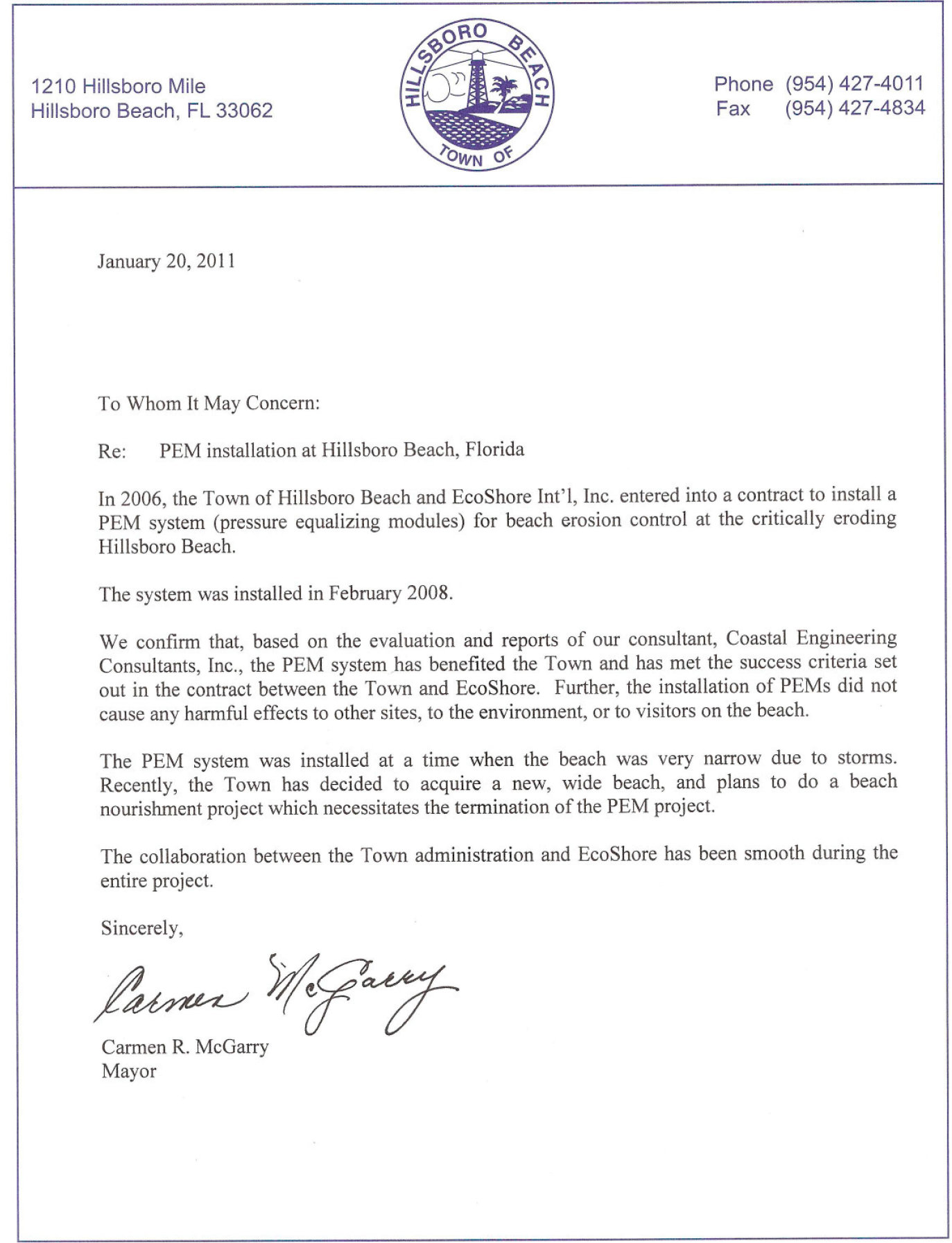

www.townofhillsborobeach.com 


\section{REFERENCES}

Burney, C.M. 2009. Hillsboro Beach Pressure Equalizing Modules Experimental Project Sea Turtle Monitoring Report January 2010, Nova Southeastern University, Oceanographic Center, Florida

CEC. 2007. Hillsboro Beach PEM Installation, the Experimental Test Plan, Coastal Engineering Consultants, Naples, Florida

Christensen, K.W., Nettles, S., and Gable, F.J., 2015. Passive dewatering. A soft way to extend the life of beach nourishments. FSBPA Technical Conference February 2015,

https://www.fsbpa.com/2015TechPresentations/Christensen.pdf

Ekkelenkamp, H.M. 2011. Drainage tubes versus sediment, MSc thesis, Delft University of Technology

Olsen and Associates, Inc. 2008. Broward County Shore Protection Project - Segment III, Broward County, Florida 1-Year Post-Construction Hillsboro Beach / Deerfield Beach Physical Monitoring Analysis Report, January 2008

Turner and Leatherman. 1997. Beach dewatering as a "soft" engineering solution to coastal erosion - a history and critical review, Journal of Coastal Research 13(4), pp. 1050-1063. 